\title{
The cytokine and chemokine expression profile of nucleus pulposus cells: implications for degeneration and regeneration of the intervertebral disc
}

Kate L E Phillips', Neil Chiverton², Anthony LR Michael², Ashley A Cole², Lee M Breakwell², Gail Haddock', Rowena AD Bunning ${ }^{1}$, Alison K Cross $^{1}$ and Christine L Le Maitre ${ }^{1 *}$

\begin{abstract}
Introduction: The aims of these studies were to identify the cytokine and chemokine expression profile of nucleus pulposus (NP) cells and to determine the relationships between NP cell cytokine and chemokine production and the characteristic tissue changes seen during intervertebral disc (IVD) degeneration.

Methods: Real-time q-PCR cDNA Low Density Array (LDA) was used to investigate the expression of 91 cytokine and chemokine associated genes in NP cells from degenerate human IVDs. Further real-time q-PCR was used to investigate 30 selected cytokine and chemokine associated genes in NP cells from non-degenerate and degenerate IVDs and those from IVDs with immune cell infiltrates ('infiltrated'). Immunohistochemistry (IHC) was performed for four selected cytokines and chemokines to confirm and localize protein expression in human NP tissue samples.

Results: LDA identified the expression of numerous cytokine and chemokine associated genes including 15 novel cytokines and chemokines. Further q-PCR gene expression studies identified differential expression patterns in NP cells derived from non-degenerate, degenerate and infiltrated IVDs. IHC confirmed NP cells as a source of IL-16, CCL2, CCL7 and CXCL8 and that protein expression of CCL2, CCL7 and CXCL8 increases concordant with histological degenerative tissue changes.

Conclusions: Our data indicates that NP cells are a source of cytokines and chemokines within the IVD and that these expression patterns are altered in IVD pathology. These findings may be important for the correct assessment of the 'degenerate niche' prior to autologous or allogeneic cell transplantation for biological therapy of the degenerate IVD.
\end{abstract}

\section{Introduction}

Intervertebral discs (IVDs) are amphiarthroses that function to permit flexion, extension and lateral bending of the spine. IVDs comprise three distinct tissue regions; the endplates, the annulus fibrosus (AF) and the nucleus pulposus (NP). The NP is the central gelatinous region and consists of a sparse cell population [1] within a complex hydrated extracellular matrix (ECM) of collagen fibres and hydrophilic proteoglycans [2]. The NP is

\footnotetext{
*Correspondence: c.lemaitre@shu.ac.uk

${ }^{1}$ Biomedical Research Centre, Sheffield Hallam University, Howard Street, Sheffield, South Yorkshire S1 1WB, UK

Full list of author information is available at the end of the article
}

constrained around the periphery by the fibrous concentric lamella of the AF, and above and below by the endplates and the vertebral bodies that each IVD separates.

IVD degeneration is a non-inflammatory arthropathy; as such, the detrimental tissue remodelling events that occur result from alterations in the behaviour of the native cell population. During degeneration, the NP is the site of specific characteristic tissue changes whereby the hydrated gelatinous ECM is condensed and replaced by a more fibrous structure [3]. These structural changes compromise the biomechanics of the IVD, and can lead to prolapse [4].

\section{Ciomed Central}

(c) 2013 Phillips et al.; licensee BioMed Central Ltd. This is an open access article distributed under the terms of the Creative Commons Attribution License (http://creativecommons.org/licenses/by/2.0), which permits unrestricted use, distribution, and reproduction in any medium, provided the original work is properly cited. 
In degeneration, alterations in native NP cell behaviour occur in respect of proliferation [5], differentiation [6-8], dysregulated metabolism [3,9] and cell death [10,11]. Cytokines are implicated as stimulus for the characteristic alterations in cell behaviour. IL- 1 and TNF- $\alpha$ are produced within the IVD, and expression levels are increased in degeneration [12-16]. Further, it is reported that in vitro IL-1 or TNF- $\alpha$ stimulation disrupts cellular metabolism in a similar manner to that seen in IVD degeneration [15,17-19]. However, in IVD prolapse, which can occur independently (as a result of exceeding the physiological limit of flexion or compressive force through a motion segment $[20,21]$, or as a secondary complication of IVD degeneration [22], locally produced cytokines may form part of the mechanism of spontaneous resorption. The spontaneous resorption of prolapsed lumbar IVD tissue has frequently been observed [23-25] although the exact mechanisms by which this occur are not yet fully understood. Inflammatory and autoimmune responses provoked in the innate and adaptive immune systems on detection of displaced tissue likely play a role, with infiltrating monocytes [26], macrophages [26-29], T and B lymphocytes [27,28] and fibroblasts [29] reported in prolapsed NP tissue.

To understand the pathogenesis of degeneration, it is important to determine the factors present within the IVD that may elicit behavioural effects on the cells present. Currently, several research initiatives are investigating the regenerative potential of autologous or allogeneic cell transplantation, and mesenchymal or adipose-derived stem-cell transfer to enhance the degenerate native cell population [30-35]. To this end, an understanding of the micro-environmental conditions of the degenerate niche would provide indication as to the factors that may act upon cells, native or introduced, to such an environment. Expression of several cytokines and chemokines (chemoattractant cytokines) have been identified within the IVD [14,26,36-38], although, with the exception of IL-1 and TNF- $\alpha$, the cellular source and biological activities of these factors has not been well studied [12,15]. In these investigations, we address the hypothesis that cytokines and chemokines are integral to the pathogenesis of IVD degeneration and prolapse. Specifically, we aimed to identify the cytokine and chemokine expression profile of NP cells and the relationships between cytokine and chemokine production, and the characteristic tissue changes seen during IVD degeneration.

\section{Methods}

\section{Human IVD tissue samples}

Fifty human lumbar IVD tissue samples were obtained for use in this study, either at surgery or post-mortem examination (PM) with informed consent of the patient or relatives (Table 1). Local ethics approval was given for this work by Sheffield Research Ethics Committee (09/H1308/70).

\section{PM tissue}

Eight IVDs were recovered from two donors with no recorded history of IVD disease or low back pain. They consisted of whole IVDs from which full-thickness wedges of $120^{\circ}$ of arc were removed anteriorly for processing to paraffin wax. Remaining NP tissue was washed in sterile phosphate-buffered saline and placed for NP cell isolation.

\section{Surgical tissue}

Forty-two NP samples were recovered from patients undergoing microdiscectomy surgery for alleviation of root pain related to IVD prolapse at Northern General Hospital, Sheffield, UK. Surgical samples consisted of multiple fragments of NP tissue with some samples containing fragments of NP with AF or cartilaginous endplate (CEP) attached. All surgical samples were assessed macroscopically upon receipt at the processing laboratory; where possible, one large fragment of NP only was divided into two, with one half being processed to paraffin wax and the other half placed for cell isolation; any remaining smaller fragments were also processed to paraffin wax. Samples containing multiple small NP fragments or a mixture of small and large NP fragments where the large fragments had AF or CEP attached were processed in their entirety to paraffin wax.

\section{Processing to paraffin wax, routine histology and immunohistochemistry for sample grading}

Tissue samples were fixed in 10\% neutral buffered formalin (Leica, Milton Keynes, UK) and processed to paraffin wax on a Shandon Elliott Duplex Processor. Haematoxylin and eosin stained sections were evaluated independently by two researchers (KLEP and CLLM) to determine the extent of degenerative tissue changes. Sections were scored numerically between 0 and 12 based on the presence of cell clusters, fissures, loss of demarcation and haematoxophilia (indicating reduced proteoglycan content); a score of 0 to 3 indicates a histologically normal (nondegenerate) IVD and a grade $\geq 4$ indicates evidence of degeneration, as described previously [15]. Inter-observer scores were averaged and assigned to each tissue sample. Sections were also taken for routine immunohistochemical (IHC) analysis of CD11b expression. CD11b is a leukocyte adhesion molecule and was used to identify immune cell infiltrates in NP tissue samples from prolapsed IVDs. CD11b IHC analysis was performed as described in the IHC method below, using a rabbit polyclonal primary antibody (1:50). Samples were classified as infiltrated on the basis of CD11b immunopositivity. 
Table 1 Tissue donor and sample classification details

\begin{tabular}{|c|c|c|c|c|c|c|c|c|c|}
\hline \multicolumn{5}{|c|}{ Donor details } & \multicolumn{5}{|c|}{ Sample classification } \\
\hline Ref. & Source & Age (y) & Level & Intact & cDNA & IL-16 IHC & CCL2 IHC & CCL7 IHC & CXCL8 IHC \\
\hline 1 & $\mathrm{~S}$ & 42 & $L 4 / L 5$ & No & I & $4.0^{*}$ & $4.0^{*}$ & $4.2^{*}$ & $4.0^{*}$ \\
\hline 2 & S & 40 & $\mathrm{~L} 5 / \mathrm{S} 1$ & Yes & I & $7.3^{*}$ & $7.3^{*}$ & $5.7^{*}$ & $7.3^{*}$ \\
\hline 3 & S & 25 & $\llcorner 4 / L 5$ & Yes & $D$ & 4 & 4 & 4.7 & 4 \\
\hline 4 & S & 48 & $\llcorner 4 / L 5$ & Yes & NA & $4.0^{*}$ & $4.0^{*}$ & $5.7^{*}$ & $4.0^{*}$ \\
\hline 5 & S & 33 & $\mathrm{~L} 5 / \mathrm{S} 1$ & Yes & $\mathrm{D}$ & NA & NA & NA & NA \\
\hline 6 & S & NA & NA & NA & NA & $6.0^{*}$ & $6.0^{*}$ & $7.0^{*}$ & $6.0^{*}$ \\
\hline 7 & S & 62 & $\llcorner 4 / L 5$ & Yes & NA & 7.5 & 7.5 & 7.3 & 7.5 \\
\hline 8 & S & 32 & $\mathrm{~L} 5 / \mathrm{S} 1$ & Yes & $\mathrm{N}$ & 2.3 & 2.3 & 3 & 2.3 \\
\hline 9 & S & 26 & $\mathrm{~L} 5 / \mathrm{S} 1$ & Yes & NA & NA & 3.3 & NA & 3.3 \\
\hline 10 & S & 53 & L4/L5 & No & NA & $7.5^{*}$ & $7.5^{*}$ & $7.5^{*}$ & $7.5^{*}$ \\
\hline 11 & S & 40 & L5/S1 & Yes & NA & 7.4 & 7.4 & 5.5 & 7.4 \\
\hline 12 & S & 66 & L5/S1 & NA & NA & $5.7^{*}$ & $5.7^{*}$ & $5.5^{*}$ & $5.7^{*}$ \\
\hline 13 & $S$ & 34 & L4/L5 & Yes & NA & 6.2 & 6.2 & 7.5 & 6.2 \\
\hline 14 & S & NA & NA & Yes & D & NA & NA & NA & NA \\
\hline 15 & $S$ & 45 & L5/S1 & Yes & $D$ & NA & NA & NA & NA \\
\hline 16 & S & 26 & L4/L5 & Yes & I & NA & NA & NA & NA \\
\hline 17 & S & 23 & $\llcorner 4 /\llcorner 5$ & Yes & $\mathrm{N}$ & NA & NA & NA & NA \\
\hline 18 & S & 29 & L4/L5 & Yes & I & NA & NA & NA & NA \\
\hline 19 & S & 35 & L5/S1 & No & $\mathrm{N}$ & NA & NA & NA & NA \\
\hline 20 & S & 20 & L4/L5 & No & 1 & NA & NA & NA & NA \\
\hline 21 & S & 39 & L5/S1 & No & 1 & NA & NA & NA & NA \\
\hline 22 & PM & 45 & $\llcorner 4 / L 5$ & Yes & $\mathrm{N}$ & 1.8 & 1.8 & 2 & 1.8 \\
\hline 23 & PM & 45 & L3/L4 & Yes & $\mathrm{N}$ & 3 & 3 & 2.5 & 3 \\
\hline 24 & PM & 45 & L5/S1 & Yes & NA & 3.5 & 3.5 & 3.5 & 3.5 \\
\hline 25 & S & 48 & L4/L5 & No & D & 9.5 & 9.5 & 6 & 9.5 \\
\hline 26 & S & 26 & L5/S1 & No & D & 11 & 11 & 3.5 & 11 \\
\hline 27 & S & 33 & $\mathrm{~L} 5 / \mathrm{S} 1$ & Yes & 1 & $8.5^{*}$ & $8.5^{*}$ & $6.5^{*}$ & $8.5^{*}$ \\
\hline 28 & PM & NA & $\mathrm{L} 1 / \mathrm{L} 2$ & Yes & NA & 10 & 10 & 6 & 10 \\
\hline 29 & PM & NA & L4/L5 & Yes & NA & 8 & 8 & 6 & 8 \\
\hline 30 & PM & NA & $\mathrm{L} 5 / \mathrm{S} 1$ & Yes & NA & 7 & 7 & 9 & 7 \\
\hline 31 & PM & NA & L3/L4 & Yes & NA & 8 & 8 & 7.3 & 8 \\
\hline 32 & PM & NA & L2/L3 & Yes & NA & 11 & 11 & 10.3 & 11 \\
\hline 33 & $S$ & 42 & L5/S1 & Yes & $\mathrm{N}$ & NA & NA & NA & NA \\
\hline 34 & $S$ & 36 & L5/S1 & Yes & $D$ & 8 & 8 & 4 & 8 \\
\hline 35 & S & 41 & L5/S1 & Yes & D & 7.5 & NA & 7.5 & NA \\
\hline 36 & $S$ & NA & NA & NA & 1 & $6.0^{*}$ & $6.0^{*}$ & $4.7^{*}$ & $6.0^{*}$ \\
\hline 37 & $S$ & 44 & L5/S1 & Yes & I & $3.0^{*}$ & $3.0^{*}$ & $2.3^{*}$ & $3.0^{*}$ \\
\hline 38 & S & 52 & L4/L5 & Yes & D & 10.5 & 10.5 & 7 & 10.5 \\
\hline 39 & $S$ & NA & $\llcorner 4 / L 5$ & No & 1 & $9.0^{*}$ & $9.0^{*}$ & $6.2^{*}$ & $9.0^{*}$ \\
\hline 40 & $S$ & 38 & L5/S1 & No & 1 & $5.8^{*}$ & $5.8^{*}$ & $5.2^{*}$ & $5.8^{*}$ \\
\hline 41 & S & 28 & $\llcorner 4 /\llcorner 5$ & Yes & D & 7.7 & 7.7 & 3.5 & 7.7 \\
\hline 42 & S & 43 & L5/S1 & No & $D$ & NA & NA & NA & NA \\
\hline 43 & S & 44 & L5/S1 & Yes & D & NA & NA & NA & NA \\
\hline
\end{tabular}


Table 1 Tissue donor and sample classification details (Continued)

\begin{tabular}{|c|c|c|c|c|c|c|c|c|c|}
\hline 44 & S & 28 & $\mathrm{~L} 5 / \mathrm{S} 1$ & No & D & NA & NA & NA & NA \\
\hline 45 & S & 35 & L5/S1 & Yes & D & NA & NA & NA & $\mathrm{NA}$ \\
\hline 46 & S & 43 & L5/S1 & No & D & NA & NA & NA & NA \\
\hline 47 & S & 42 & L5/S1 & No & D & NA & NA & NA & NA \\
\hline 48 & S & 62 & L3/L4 & Yes & I & NA & NA & NA & NA \\
\hline 49 & $\mathrm{~S}$ & 40 & L3/L4 & Yes & D & NA & NA & NA & NA \\
\hline 50 & S & 45 & $\llcorner 4 /\llcorner 5$ & No & 1 & NA & NA & NA & NA \\
\hline
\end{tabular}

S, surgical; PM, post-mortem; I, infiltrated; D, degenerate; N, non-degenerate, IHC, immunohistochemistry; $C C L, C-X-C$ chemokine. Surgically obtained prolapsed tissue samples were considered to be from intact IVDs when no signs of annulus fibrosus or cartilaginous endplate rupture were evident (protrusion-type prolapse).

Values given for IHC sample classification are average histologically determined grades of degeneration; *infiltrating immune cells were observed; NA, not applicable.

\section{Grade assignment for CDNA samples}

On account of the heterogeneity often observed in prolapsed IVD tissues [39], serial sections were made from paraffin-embedded tissues that had matched cDNA samples derived from surgically obtained NP. Routine histological and IHC examinations were made on multiple sections, at different levels throughout the paraffin-embedded tissue, to ensure assessment of any heterogeneity. cDNA samples were only considered to be from non-degenerate tissue if all haematoxylin and eosin stained sections were assigned a histological grade of degeneration $<4$. cDNA samples were considered to be from an infiltrated IVD if CD11b immunopositivity (indicating leukocyte presence) was observed in any tissue section evaluated.

\section{Grade assignment for immunohistochemistry samples}

For each tissue section used in IHC evaluation, routine histology was performed on an adjacent serial section. By this method, the grade of degeneration assigned is relevant to the tissue assessed by IHC even in surgically obtained tissue samples where heterogeneity is sometimes observed.

\section{Cell isolation and generation of cDNA samples}

NP tissue samples were finely minced and digested with $2 \mathrm{U} / \mathrm{ml}$ protease (Sigma, Poole, UK) in DMEM (Gibco, Paisley, UK) for 30 minutes at $37^{\circ} \mathrm{C}$, followed by $2 \mathrm{mg} / \mathrm{mL}$ collagenase type I (Sigma) in DMEM for 4 hours at $37^{\circ} \mathrm{C}$. Cells were recovered by centrifugation and RNA extracted immediately from $1 \times 10^{5}$ cells using tri-reagent (Invitrogen, Paisley, UK). Genomic DNA contamination was eliminated by DNase treatment (Qiagen, Crawley, UK) prior to RNA purification by MinElute Cleanup kit (Qiagen) as per manufacturer's protocol. cDNA was reverse transcribed using Moloney Murine Leukaemia Virus reverse transcriptase (Bioline, London, UK) and random hexamers (Applied Biosystems, Warrington, UK).

\section{CDNA low density array}

In total, six cDNA samples were interrogated by realtime PCR low density array (LDA; Applied Biosystems) for the expression of 91 cytokine- and chemokineassociated genes. Three cDNA samples were selected from each of two study groups; non-degenerate (mean age 34 years, range 25 to 45 ) and degenerate (mean age 32 years, range 29 to 33), according to routine histological examination of matched paraffin-embedded tissues. Briefly, a mastermix was prepared for each sample and $20 \mu \mathrm{L}$ per well loaded onto 96-well $\mathrm{FAST}^{\bullet}$ LDA plates - equivalent to $2 \mu \mathrm{L} \mathrm{cDNA}, 10 \mu \mathrm{L} \mathrm{Taqman}^{\circ} \mathrm{FAST}^{\circ}$ universal mastermix (Applied Biosystems) and $8 \mu \mathrm{L}$ sterile deionised water per well. Plates were run on a StepOnePlus real-time PCR machine (Applied Biosystems) on a FAST ${ }^{\circ}$ programme incorporating 50 cycles of denaturation at $95^{\circ} \mathrm{C}$ for 1 second followed by annealing and extension at $60^{\circ} \mathrm{C}$ for 20 seconds. Measurements were performed in duplicate, averaged and normalised to expression of five internal reference genes. Full details of LDA plate design are available online (see Additional file 1). Following analysis of cDNA, LDA data-targets were selected for further investigation by real-time PCR and IHC (Figure 1).

\section{Real-time PCR}

Following LDA analysis 30 cytokine- and chemokineassociated genes were selected for further investigation by real-time q-PCR. In total, 35 cDNA samples (Table 1) were divided into three study groups; non-degenerate, degenerate and infiltrated according to routine histological and IHC examination of matched paraffin-embedded tissues, and subjected to gene expression analysis. Briefly, a mastermix was prepared for each target gene investigated and $8 \mu \mathrm{L}$ per well loaded onto 96-well FAST ${ }^{\circ}$ PCR plates equivalent to $5 \mu \mathrm{L}$ Taqman $^{\circ}$ FAST $^{\circ}$ universal mastermix (Applied Biosystems), $2.5 \mu \mathrm{L}$ sterile deionised water and 0.5 $\mu \mathrm{L}$ Taqman ${ }^{\circ}$ gene expression assay (Applied Biosystems) per well, alongside $2 \mu \mathrm{L}$ sample cDNA. Plates were run on a StepOnePlus real-time PCR machine as described above. Measurements were performed in duplicate, averaged and normalised to expression of two internal reference genes (GAPDH and 18S). Full details of Taqman ${ }^{\circ}$ gene expression assays used are available online (see Additional file 1). 


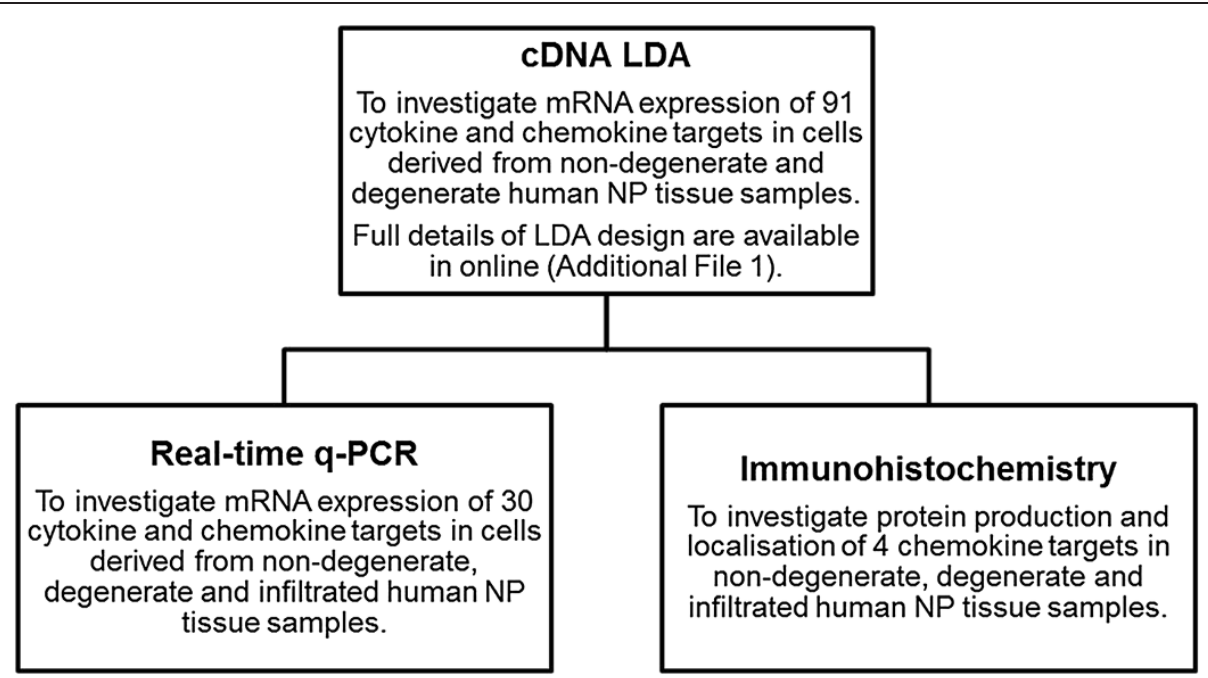

Figure 1 Study outline and experimental approaches. Initial low density array (LDA) analysis of cells isolated from human nucleus pulposus (NP) tissue samples identified a diverse cytokine and chemokine expression profile. From these data, 30 targets were selected for further gene expression analysis by real-time qPCR and 4 targets were selected for protein production and localisation analysis by immunohistochemistry. Consideration was given to the frequency at which targets were detected and any differential expression profile observed between non-degenerate and degenerate study groups to select targets for further investigation. Consideration was also given to the detection of receptor mRNA expression (indicating potential for autocrine or paracrine signalling involvement), whether the roles of identified targets had previously been well studied, the identification of novel targets within the intervertebral disc, and links to cytokine and chemokine activity in other arthropathies.

\section{Immunohistochemistry}

Four chemokines were selected for IHC investigation of protein production and localisation following LDA analysis of gene expression. Expression of each target chemokine was investigated in 30 IVD tissue samples (Table 1), divided between three study groups; non-degenerate, degenerate and infiltrated, according to routine histological and IHC examination. Briefly, 4- $\mu \mathrm{m}$ paraffin sections were de-waxed, rehydrated and endogenous peroxidase-blocked using hydrogen peroxide. After washing in tris-buffered saline (TBS; $20 \mathrm{mM}$ tris, $150 \mathrm{mM}$ sodium chloride, $\mathrm{pH}$ 7.5), sections were subjected to heat-induced antigen retrieval (10-minute microwave irradiation in $0.05 \mathrm{M}$ tris buffer, pH 9.5). Following TBS washing, nonspecific binding sites were blocked at room temperature for 90 minutes with $25 \%$ w/v goat serum (Abcam, Cambridge, UK) in 1\% w/v bovine serum albumin in TBS. Sections were incubated overnight at $4^{\circ} \mathrm{C}$ with rabbit polyclonal primary antibodies against human IL-16 (1:750), CCL2 (1:500), CCL7 (1:10,000) and CXCL8 (1:100). Negative controls in which rabbit IgGs (Abcam) replaced the primary antibody at an equal protein concentration were used. After washing in TBS, sections were incubated in biotinylated goat anti-rabbit antiserum (1:500; Abcam) for 30 minutes at room temperature. Disclosure of secondary antibody binding was by the streptavidinbiotin complex (Vector Laboratories, Peterborough, UK) technique with $0.08 \% \mathrm{v} / \mathrm{v}$ hydrogen peroxide in $0.65 \mathrm{mg} / \mathrm{mL} 3,3$ '-diaminobenzidine tetrahydrochloride (Sigma) in TBS. Sections were counterstained with
Mayer's Haematoxylin (Leica), dehydrated, cleared and mounted in Pertex (Leica).

All slides were visualised using an Olympus BX60 microscope and images captured using a digital camera and software program QCapture Pro v8.0 (MediaCybernetics, Marlow, UK). Evaluation of IHC staining was performed by counting $200 \mathrm{NP}$ cells, with immunopositive cells expressed as a percentage of total count. A polarizing filter was used during slide evaluation to ensure cells counted were within NP tissue only, as any AF fragments can be identified by differential collagen-fibre arrangement visible under polarized light. Since the majority of samples collected for use in this study consisted of NP tissue only, no attempt was made to quantify immunopositivity in AF or CEP IVD regions.

\section{Statistical analysis}

Statistical analysis of LDA and q-PCR data was performed against two parameters; where mRNA expression was detected, the Mann-Whitney test (for LDA) or Kruskal-Wallis combined with the Conover-Inman post hoc test (for q-PCR) was used to investigate significant differences in expression level between study groups; when the frequency at which expression was detected was not equivalent between study groups, the twosample test of proportionality was used to investigate significant differences in detection frequency. Statistical analysis of IHC data was performed against two parameters; the Kruskal-Wallis test was used to investigate significant differences in expression level between study 
groups, and linear regression analysis was used to investigate correlations between measured protein expression and the extent of degenerative tissue changes.

\section{Results}

A diverse cytokine and chemokine mRNA expression profile was identified in total cells isolated from human NP tissue specimens

cDNA LDA was performed to assess the diversity and extent of cytokine- and chemokin-associated gene expression by cells isolated from NP tissue. An extensive gene expression profile was detected, including 15 cytokines and chemokines not previously identified within the IVD; IL-11, IL-16, IL-18, IL-23, TNF- $\beta$, OSM, LIF, CCL8, CCL19, CCL20, CXCL2, CXCL3, CXCL5, CXCL6 and CX ${ }_{3}$ CL1 (Figures 2 and 3). Expression of numerous receptor and signalling accessory molecules was also identified. Comparative analysis of data generated from non-degenerate and degenerate samples suggests that 16 of the identified cytokines and chemokines: $I L-1 \beta, I L-6, I L-10, I L-11$,
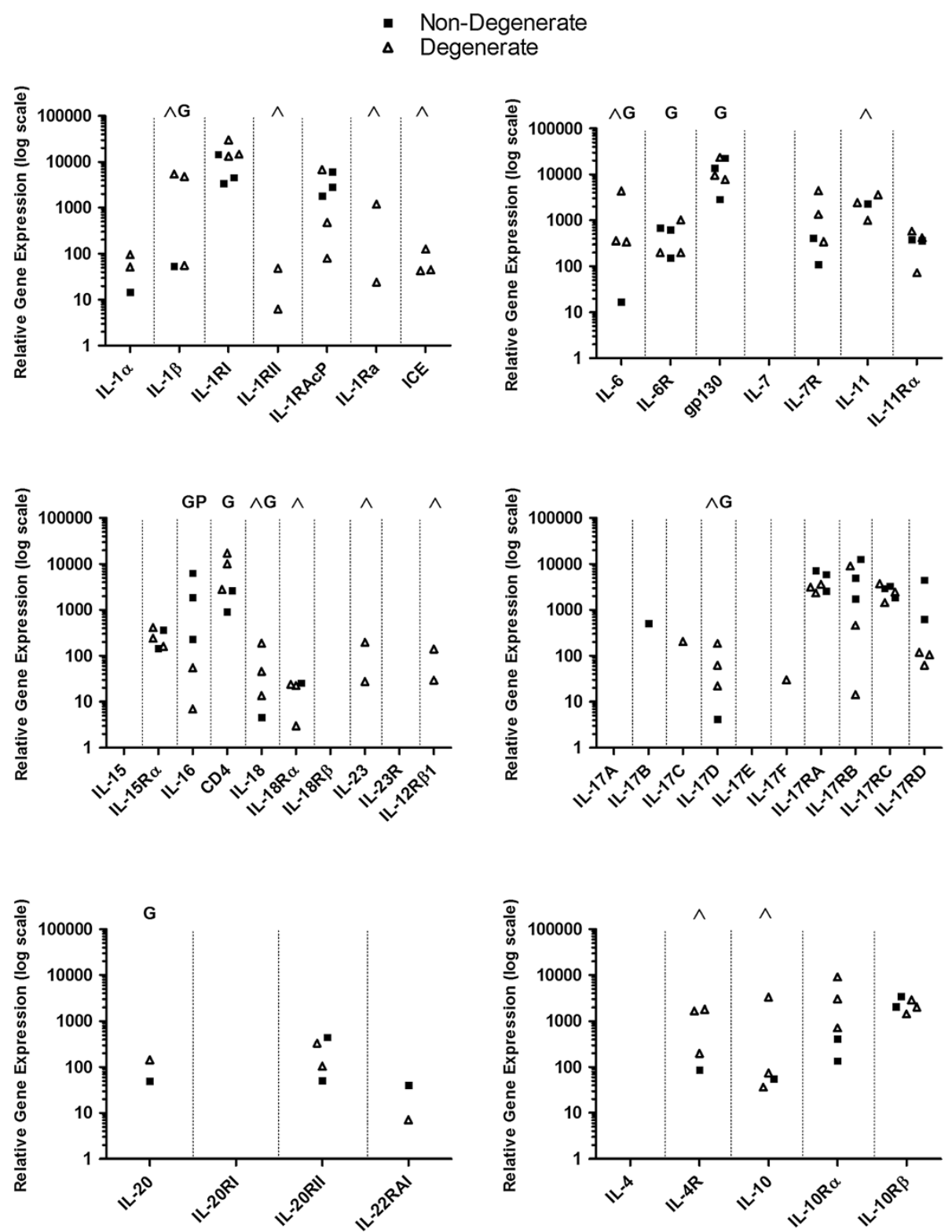

Figure 2 cDNA low density array cytokine and chemokine expression profile of NP cells. Gene expression of 36 cytokines and chemokines was detected in nucleus pulposus cells; 15 of the identified cytokines and chemokines have not been identified previously within the intervertebral disc (IVD). Comparative analysis indicates expression of 16 targets is increased in NP cells derived from degenerate IVDs. $\wedge$ Increased frequency of mRNA detection in NP cells derived from non-degenerate IVDs compared to degenerate $(P<0.05)$; $G$, further gene expression analysis performed on this target; $\mathrm{P}$, further protein expression analysis performed on this target. 


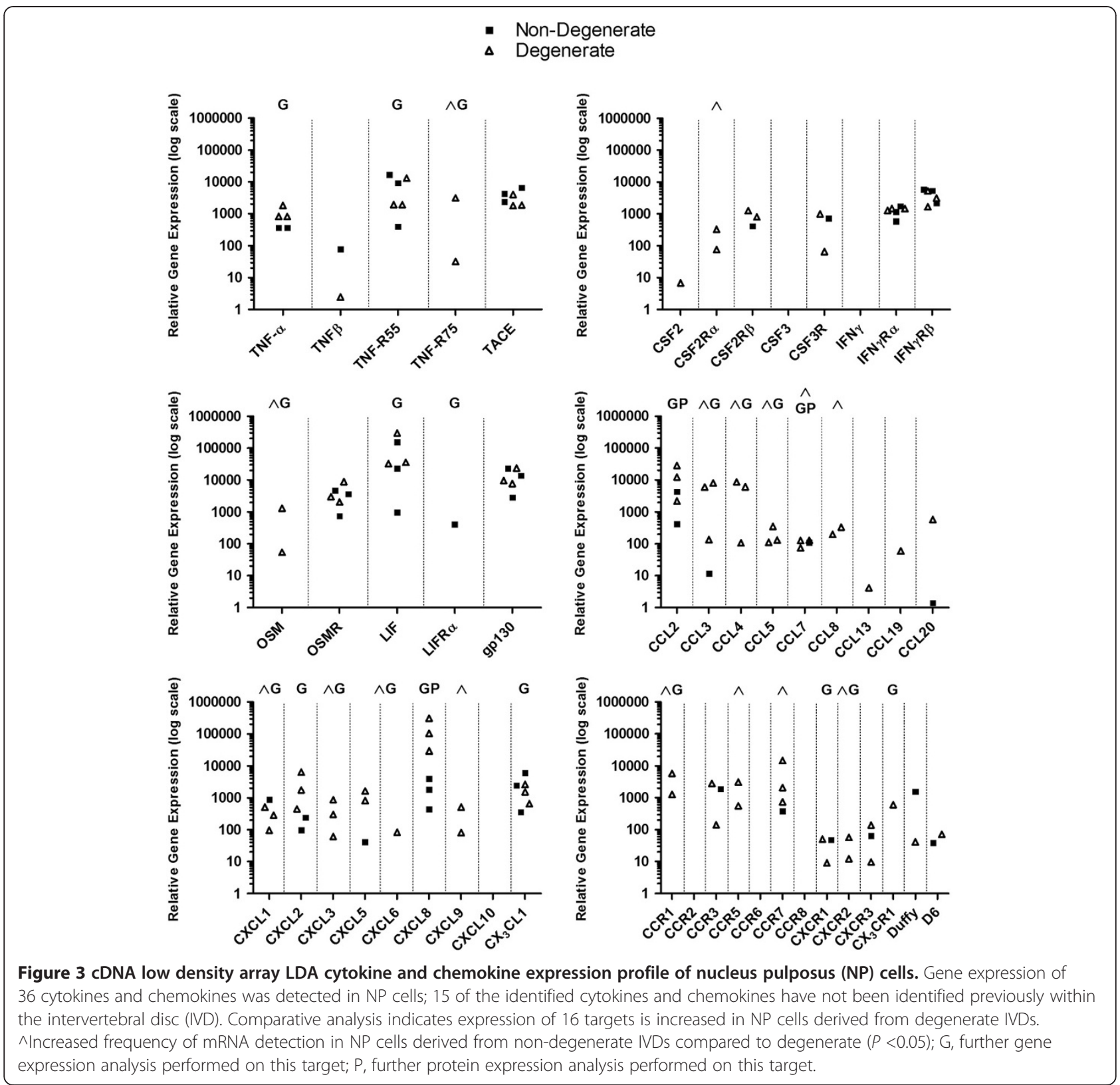

IL-17D, IL-18, IL-23, OSM, CCL3, CCL4, CCL5, CCL7, CCL8, CXCL1, CXCL3 and CXCL9, are up-regulated in degenerate samples (Figures 2 and 3 ).

For thirty cytokine- and chemokine-associated genes identified by LDA, investigations were extended to incorporate 35 cDNA samples across three study groups: nondegenerate, degenerate and infiltrated. Expression of all cytokines and chemokines investigated was detected in all study groups (Figures 4 and 5). In most cases, expression of cytokine and chemokine receptors were detected across study groups, with the exceptions of LIFR, which was only detected within non-degenerate samples, $C X C R 2$ and $C X_{3} C R 1$, which were only detected in degenerate and infiltrated samples and $C C R 2$, which was not detected in any NP cell sample investigated (Figures 4 and 5).

To ascertain if differential cytokine and chemokine expression profiles are associated with IVD degeneration or are attributable to immune-cell infiltration, comparative analysis was performed across study groups. Differential expression profiles were observed in relation to both the relative level of mRNA expression and frequency at which mRNA expression was detected. Relative expression levels of $I L-17 D, L I F$ (Figure 4), CCL2, CXCL2 and $C X_{3} C L 1$ (Figure 5) were decreased in degenerate samples compared to non-degenerate $(P<0.05$ in all cases $)$ while CXCL8 expression was detected more frequently in degenerate samples compared to non-degenerate (Figure 5; 

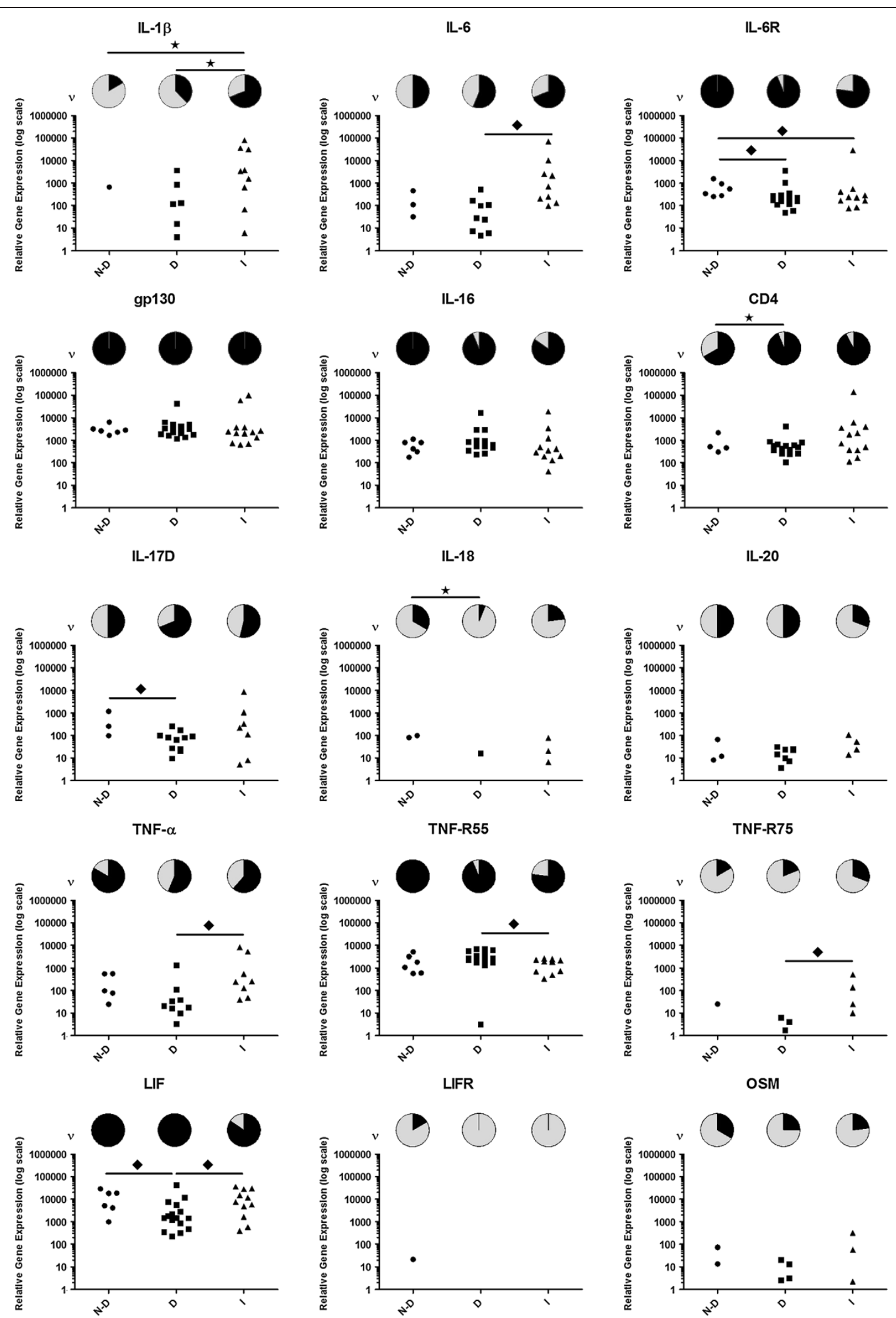

Figure 4 (See legend on next page.) 
$P<0.05)$. $I L-6$ and $I L-16$ mRNA expression was equivalent between non-degenerate and degenerate study groups although the relative expression level of IL-6 receptor $(I L-6 R)$ was decreased in degenerate samples, whereas detection frequency of CD4 (IL-16 receptor) was increased (Figure 4; $P<0.05$ in both cases).

$I L-1 \beta$ (Figure 4) and CCL3 (Figure 5) expression was detected more frequently in infiltrated samples compared to non-degenerate, whereas $C X_{3} C L 1$ was detected less frequently in infiltrated samples compared to non-degenerate $(P<0.05$ in all cases). A similar pattern to that seen in degenerate samples was observed in infiltrated samples for $I L-6 R$ expression (Figure 4), where relative expression level was decreased compared to non-degenerate samples $(P<0.05)$. CXC chemokine expression was not significantly altered between non-degenerate and infiltrated samples although detection frequency of receptor CXCR2 was increased in infiltrated samples compared to nondegenerate (Figure $5 ; P<0.05$ ).

Comparative analysis was also performed between the two pathological study groups. Overall, greater cytokine and chemokine expression was detected in infiltrated samples compared to degenerate. $I L-1 \beta$ (Figure 4), CCL2 and CCL4 (Figure 5) were detected more frequently in infiltrated samples and expression levels of $I L-6, T N F-\alpha$, TNF-R75, LIF, CCL2, CCL3, CCL5, CXCL1, CXCL2, $C X C L 3$ and $C X C L 8$ were greater in infiltrated samples $(P<0.05$ in all cases $)$.

\section{Quantitation of chemokine production by NP cells in human NP tissue specimens}

To confirm that gene expression translates to protein production in vivo, expression of IL-16, CCL2, CCL7 and CXCL8 in human NP tissue was assessed by IHC. Protein production was confirmed and localised to native NP cells (Figure 6A). Although for all targets investigated, expression was also observed in immune cell infiltrates, where present, in NP tissue specimens, indicating that NP cells are not the only source of cytokines and chemokines within the IVD (Figure 6B). Assessment of percentage cellular immunopositivity localised to NP cells was used to identify differential expression profiles between study groups (Figure 7). Protein expression of CCL7 and CXCL8 localised to NP cells was increased in degenerate samples compared to non-degenerate samples $(P<0.05$ in both cases). Protein expression of CCL2 localised to NP cells was also increased, but not significantly so $(P=0.0526)$, in degenerate samples compared to non-degenerate. Expression of CCL7 and CXCL8 localised to NP cells was increased in infiltrated samples compared to nondegenerate $(P<0.05$ in both cases). Expression of CCL2 localised to NP cells was also increased, but not significantly so $(P=0.0870)$, in infiltrated samples compared to non-degenerate. IL-16 expression was equivalent across all study groups.

We then examined if degenerative tissue changes correlated with NP cell protein expression of cytokines and chemokines localised to NP cells, as determined by IHC (Figure 8). Protein expression of CCL2 and CXCL8 by NP cells increased concordant to increasing severity of degenerative tissue changes in human NP $(P=0.0067$ and $P=0.0067$ respectively). Protein expression of CCL7 also increased concordant to degenerative tissue changes, but not significantly so $(P=0.0600)$.

\section{Discussion}

In the last decade, our knowledge of cytokine effects within the IVD has increased substantially, particularly in respect of IL- 1 and TNF- $\alpha$ and the detrimental effects of elevated levels of these cytokines [12,13,15-19,37,40]. On the contrary, the full extent of cytokine and chemokine production by native IVD cells has not been fully explored [14,26,36,38]. To the best of our knowledge, the current study is the first to systematically profile cytokine and chemokine expression in NP tissue.

In cells isolated from degenerate human tissue we observed an extensive cytokine and chemokine expression profile. Cytokine and chemokine ligands were detected in most cases alongside receptors, activating enzymes and signalling accessory proteins, thus there is the potential for these ligands to act as autocrine or paracrine factors on the native NP cell population within the IVD. The effects of IL- 1 and TNF- $\alpha$ on NP cell behaviour have been investigated previously, with both factors eliciting effects on cellular metabolism [15,17-19], a parameter that is adversely affected in IVD degeneration $[3,9,41]$. Notably, it is not only the expression of IL- 1 and TNF- $\alpha$ that is increased in the degenerate IVD $[13,15]$; the cellular response to stimulation is altered $[15,18]$, as is the sensitivity of the cell population, evidenced by altered expression patterns of the receptors $[13,15,16]$. Further, imbalance between IL-1 and its natural inhibitor, IL-1 


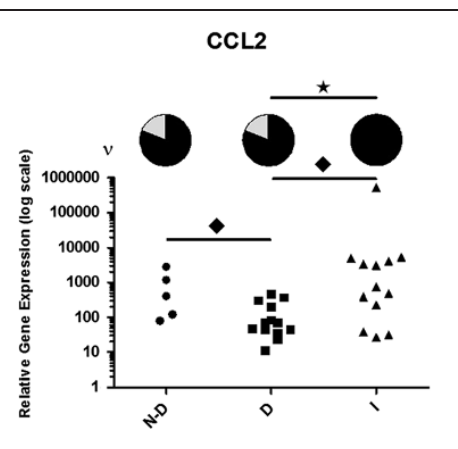

CCL5

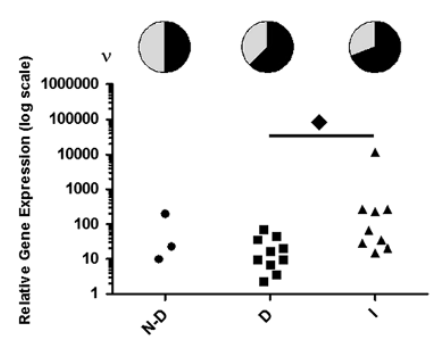

CCR2

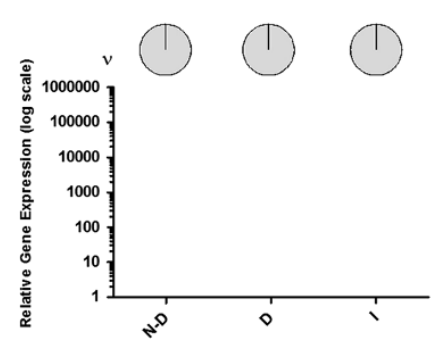

CXCL3
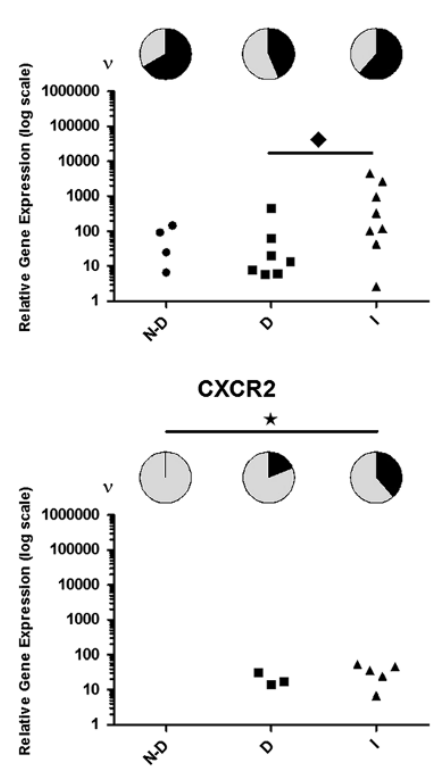

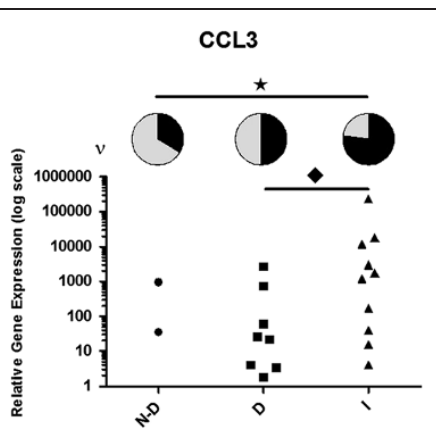

CCL7

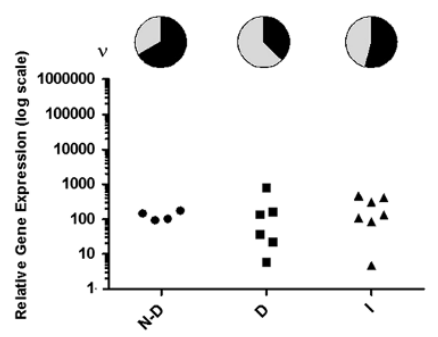

CXCL1
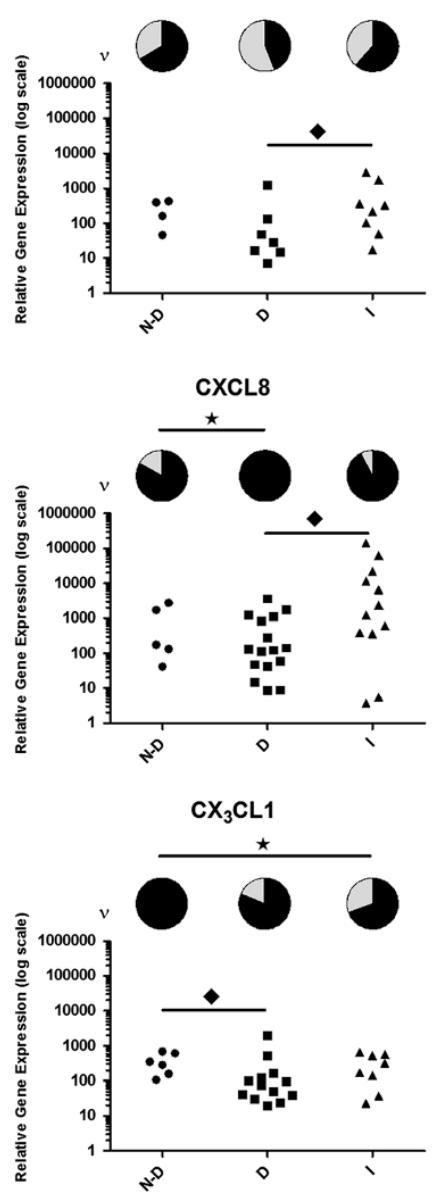

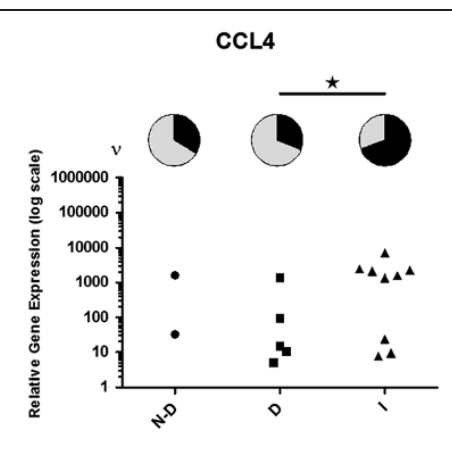

CCR1

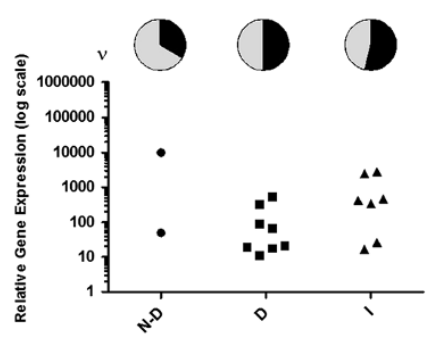

CXCL2

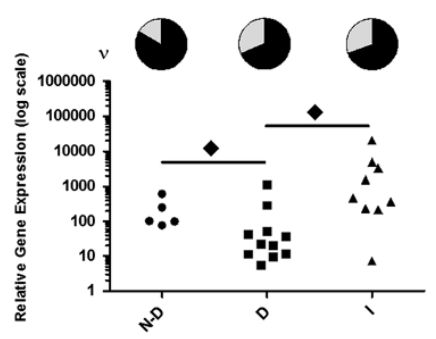

CXCR1

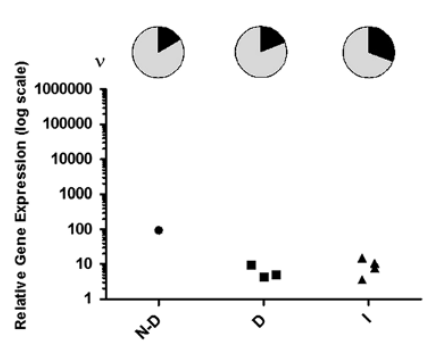

$\mathrm{CX}_{3} \mathrm{CR} 1$

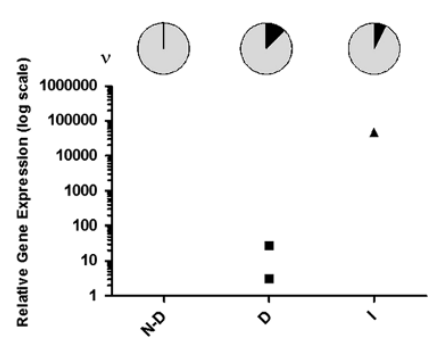

Figure 5 (See legend on next page.) 
(See figure on previous page.)

Figure 5 Chemokine-associated gene expression in nucleus pulposus (NP) cells from non-degenerate, degenerate and infiltrated intervertebral discs (IVDs). Relative mRNA quantitation of chemokines and receptors was assessed by real-time q-PCR in cDNA samples from non-degenerate, degenerate and infiltrated study groups. Data shown are detection frequency ( $\mathrm{v}$; pie charts) and relative expression per sample investigated (scatter plots). N-D, non-degenerate study group; D, degenerate study group; I, infiltrated study group; black star, significant difference in detection frequency between study groups $(P<0.05)$; black diamond, significant difference in relative expression levels between study groups $(P<0.05)$.

receptor antagonist, is reported to induce spontaneous IVD degeneration in mice [40]. Although IL-1 and TNF- $\alpha$ are implicated in the pathogenesis of IVD degeneration, both are expressed at low levels in the normal IVD, indicating a role for these factors under normal physiological conditions $[12,13,15,16]$.
Additional gene expression studies confirmed that the cytokine- and chemokine-associated gene expression profile observed in cells from degenerate IVDs was similar to that from non-degenerate and infiltrated IVDs, reinforcing the potential of these factors to act as intercellular signalling molecules under normal physiological
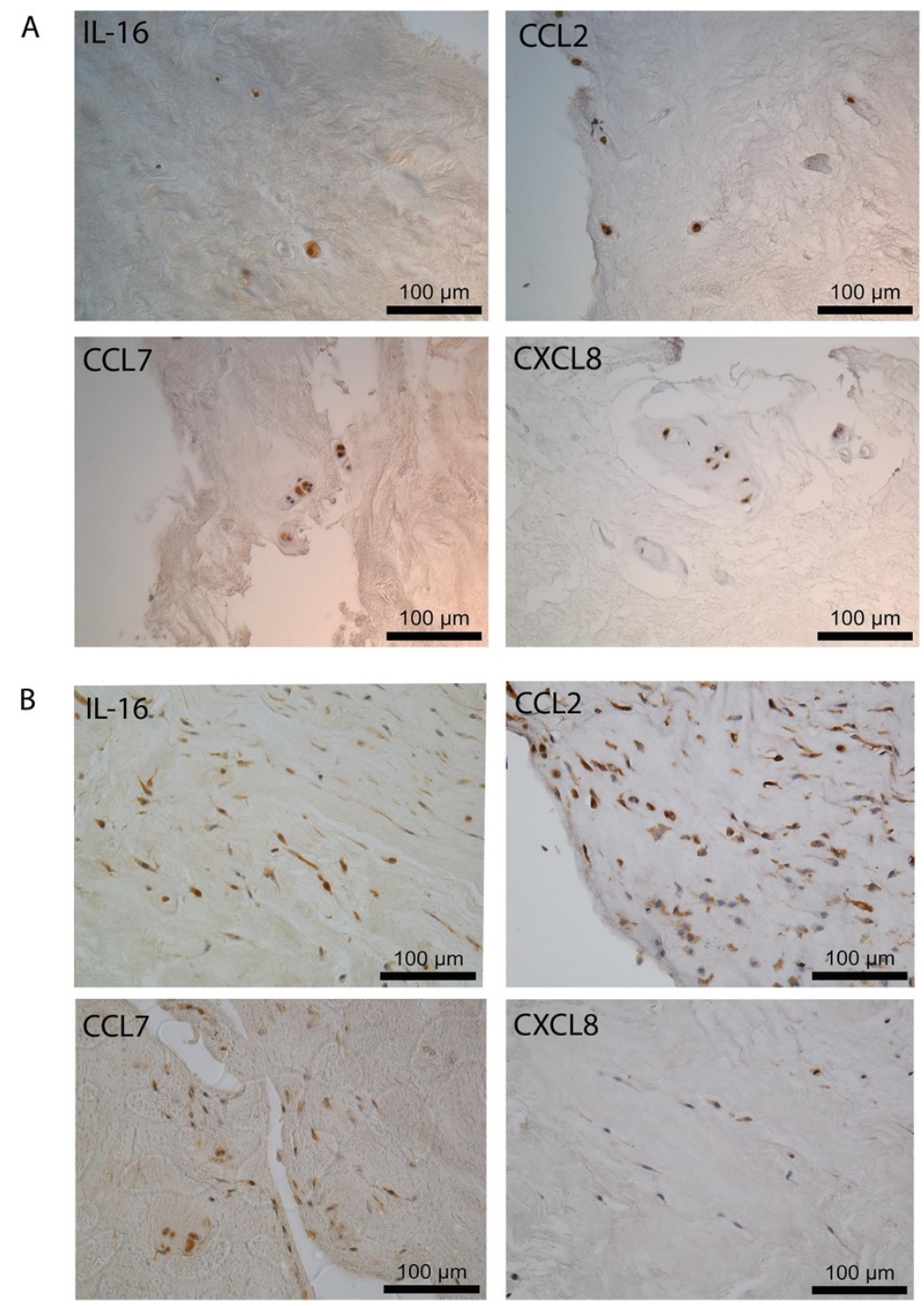

Figure 6 IL-16, CCL2, CCL7 and CXCL8 expression in nucleus pulposus (NP) tissue from prolapsed intervertebral discs (IVDs).

Representative photomicrographs showing 4- $\mu \mathrm{m}$ paraffin-embedded sections of NP tissue stained for IL-16, CCL2, CCL7 and CXCL8 (A). Abundant IL-16, CCL2, CCL7 and CXCL8 expression was observed in NP cells scattered throughout tissue sections (original magnification $\times 400$, scale bar represents $100 \mu \mathrm{m})$. IL-16, CCL2, CCL7 and CXCL8 expression was also observed in immune cell infiltrates (B). 


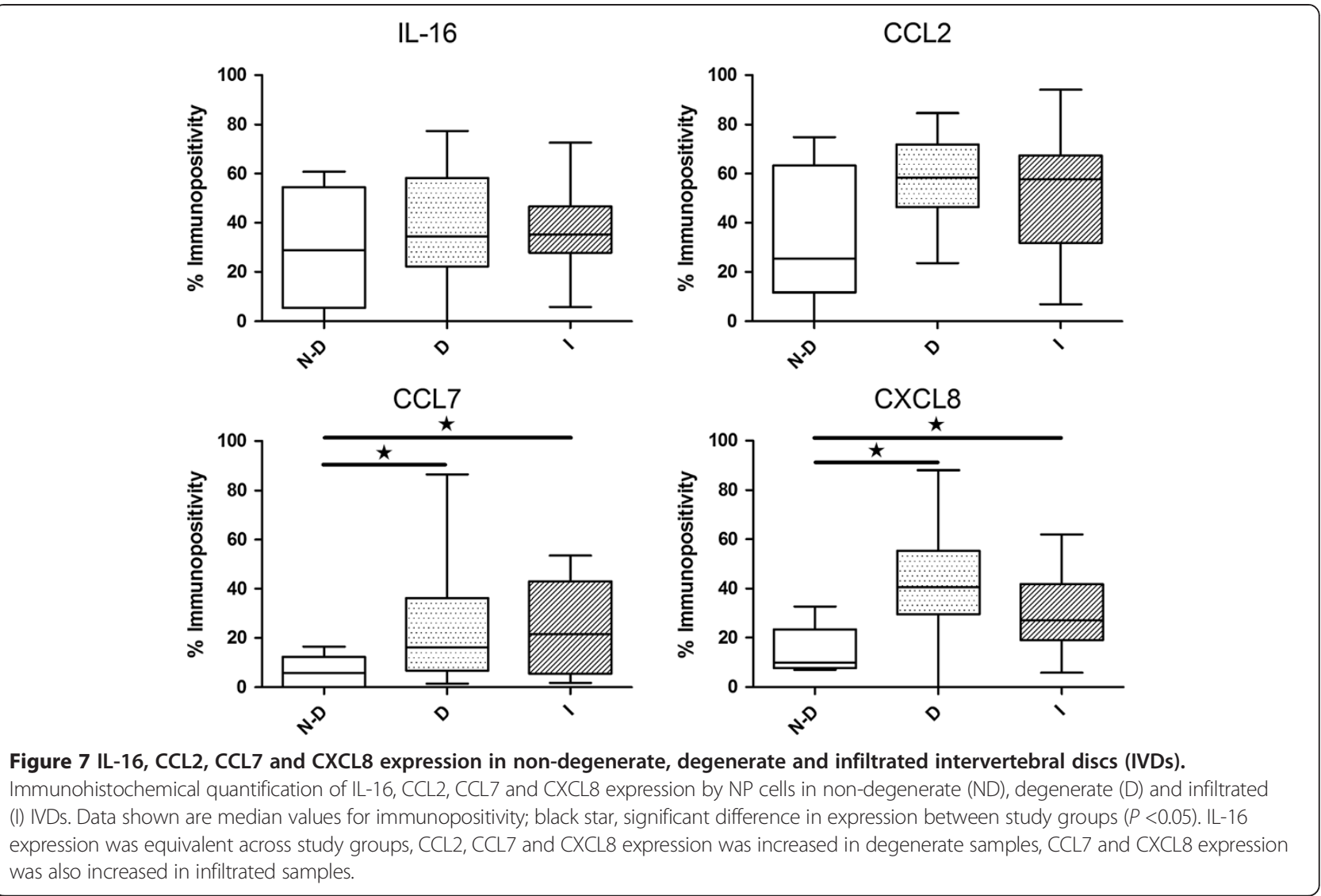

conditions and in the pathologies of IVD degeneration and prolapse. Although expression of the same factors was identified, comparative analysis indicated that differential expression patterns exist in relation to detection frequency and relative expression levels. Within the non-degenerate and degenerate study groups mRNA detection is assumed to be a result of native NP cell expression. Interestingly, at the level of mRNA detection, relative expression of several cytokine and chemokine ligands; IL-17D, LIF, CCL2, CXCL2 and $C X_{3} C L 1$ was down-regulated in degeneration. Only $C X C L 8$ mRNA expression was significantly up-regulated in degenerate samples compared to non-degenerate counterparts. In the infiltrated study group, mRNA expression may result from a combination of NP and infiltrating immune cell expression. Generally, in infiltrated samples cytokineand chemokine-associated gene expression was increased compared to both non-degenerate and degenerate samples, particularly so for $I L-1 \beta, I L-6, T N F-\alpha, C C L 3$ [37] and CXCL8 and this may be due to summated expression by native NP and infiltrating immune cells.

IHC studies confirmed that a source of cytokine and chemokine production in the IVD is the native NP cell population in respect of IL-16, CCL2, CCL7 and CXCL8, and that production is a feature of NP cells in non- degenerate and pathological IVD tissues. This agrees with previous reports of NP cell production of IL-1 [15,16], CCL3 and CCL4 [37]. Comparative analysis of NP cell production in non-degenerate, degenerate and infiltrated IVDs shows that protein expression of CCL2, CCL7 and CXCL8 is increased in degenerate and infiltrated IVDs compared to the non-degenerate counterpart. At the level of NP cell immunopositivity, no significant differences between degenerate and infiltrated study groups were observed, whereas previous gene expression analysis indicated that CCL2 and CXCL8 mRNA expression was greater in infiltrated compared to degenerate samples. This finding would again point towards infiltrating immune cells as a contributing source of CCL2 and CXCL8 expression within the IVD, as gene expression was measured in total cells isolated from tissue specimens, and IHC identified expression of IL-16, CCL2, CCL7 and CXCL8 in immune cell infiltrates, although this was not quantified. Of note, upon histological examination of tissue sections, immune-cell infiltrates were identified in tissue samples from clinically reported intact IVDs (protrusion-type prolapse). As leukocyte infiltration usually occurs following AF or CEP rupture [27-29,42] and exposure of NP tissue to the external environment of the IVD [28,43-47], a possible 


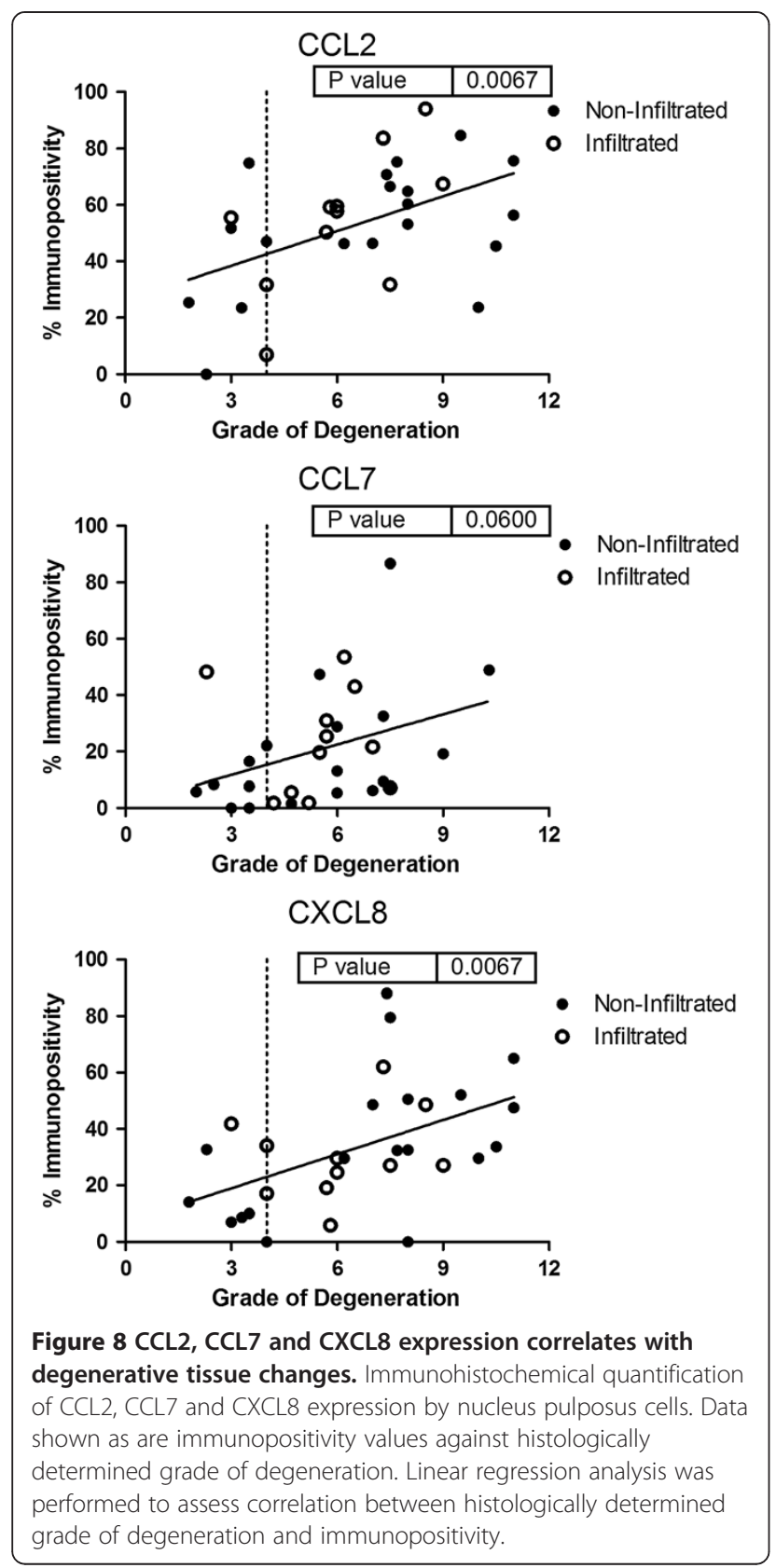

explanation for this finding is that NP tissue displaced down a radial fissure [4] may come into contact with the capillary network of the AF [48]. This would provide a direct route between blood circulation and NP tissue for circulating leukocyte entry into the intact IVD. Resolution without medical intervention has been described previously for protrusion-type IVD prolapse, and retraction of the AF is postulated to mediate this process $[24,49]$. Based on our observations, leukocyte-mediated breakdown of displaced NP tissue within the intact IVD could occur and may therefore represent a further mechanism in the process of protrusion resolution.
The context in which we sought to identify the cytokine and chemokine expression profile of the IVD was in so far as it related to the progression of IVD pathology, and to the effects that it may elicit on attempted biological therapies targeted at impeding progression of, or even reversing this pathology. In respect of IVD degeneration, pathological changes associated with altered cell behaviour are related to proliferation [5], differentiation [6-8], dysregulated metabolism [3,9] and cell death $[10,11]$. It seems reasonable to assume that if the cytokines and chemokines identified here do form part of the pathological mechanism of IVD degeneration and prolapse, their effects would be related to the adverse alterations in cell behaviour observed in IVD pathology.

Here, we attempted to systematically profile cytokine and chemokine expression in NP tissue. Initial screening of cytokine and chemokine gene expression in cells isolated from NP tissue specimens was performed by high sensitivity real-time q-PCR cDNA LDA. This method provides advantage over standard PCR detection because data collection within the exponential phase of amplification (prior to reaction saturation) makes this method fully quantifiable. Data generated therefore provide indication not just as to the levels of detection frequency in a study group, but also as to the relative expression levels within each study group. A limiting factor to this analysis, however, was the small number of samples subjected to LDA analysis. In light of the small study groups used, differential expression patterns observed between non-degenerate and degenerate study groups may not be representative of those in the wider population. Indeed, further real-time q-PCR analysis on larger study groups did not confirm all of the earlier LDA-indicated differential expression patterns.

Aside of the investigations described previously, the effects of cytokines and chemokines on NP cell behaviour have not been comprehensively studied, although their effects in other cell types have been described. Chondrocytes exhibit morphological and biochemical similarity to NP cells and so the effects of cytokines and chemokines on chondrocyte behaviour may be relevant to that of NP cells. In chondrocytes, effects of cytokine and chemokine stimulation have been described in relation to all of the common features of altered NP cell behaviour as seen in IVD degeneration. These include increased rates of proliferation [50], hypertrophic differentiation [51,52], increased catabolic metabolism [50,53,54], decreased anabolic metabolism [53,54], and induced cell death $[55,56]$. The precedents set in these investigations indicate that further investigative work into the role of cytokines and chemokines within the IVD is warranted.

Currently, several research initiatives are investigating the regenerative potential of cell therapy within the IVD [30-34]. Application of the soluble factor, transforming 
growth factor- $\beta$, elicits well-described effects on mesenchymal and adipose-derived stem cell differentiation; indeed, its application in vitro is required to stimulate differentiation towards an NP phenotype [31,35]. The survival and differentiation characteristics of stem cells injected into NP explant cultures, under conditions modelling the environment of the normal IVD have been confirmed [32]. However, the findings reported here suggest that cells implanted into the degenerate IVD would encounter a diverse and altered range of soluble factors, including cytokine and chemokine signalling molecules. The effects of these on stem cell behaviour have not been investigated and clearly the response of implanted cells to their surrounding environment will have considerable influence over the success of cell therapy to the IVD. To this end, these investigations provide insight into the conditions of the degenerate niche and indicate that further investigations to determine the effects this environment may elicit on cell behaviour are required.

\section{Conclusions}

Our data indicate that NP cells are a source of cytokines and chemokines within the IVD and that these expression patterns are altered in IVD pathology. These findings may be important for the correct assessment of the degenerate niche prior to autologous or allogeneic cell transplantation for biological therapy of the degenerate IVD.

\section{Additional file}

Additional file 1: Low density array (LDA) design. (I) Internal reference and target genes investigated by CDNA LDA; green indicates internal reference genes. Highlighted genes are those selected for inclusion in additional real-time q-PCR analysis. (II) Catalogue numbers for pre-designed primer-probe sequences used in LDA analysis. Highlighted catalogue numbers are those for assays used in additional real-time q-PCR analysis. LDAs and primer-probe assays were supplied by Applied Biosystems (UK).

\section{Abbreviations}

AF: Annulus fibrosus; CEP: Cartilaginous end plate; DMEM: Dulbecco's modified Eagle's medium; ECM: Extracellular matrix;

IHC: Immunohistochemistry; IL: Interleukin; IVD: intervertebral disc; LDA: Iow density array; LIF: leukaemia inhibitory factor; LIFR: Leukaemia inhibitory factor receptor; NP: Nucleus pulposus; PM: Post mortem; q-PCR: Quantitative polymerase chain reaction; TBS: Tris-buffered saline; TNF: Tumour necrosis factor.

\section{Competing interests}

The authors declare that they have no competing interests.

\section{Authors' contributions}

KLEP performed all laboratory work, data analysis and statistical analysis, contributed to study design and drafted the manuscript. NC contributed to study design and sample collection, helped to secure funding and critically revised the manuscript. ALRM, AAC and LMB contributed to study design, sample collection and critically revised the manuscript. GH, RADB and AKC contributed to study design, helped to secure funding and critically revised the manuscript. CLLM conceived the study, participated in its design and coordination, secured funding and critically revised the manuscript for important intellectual content. All authors read and approved the final manuscript.

\section{Acknowledgements}

Financial support for this study provided by a PhD Studentship from the Biomedical Research Centre, Sheffield Hallam University and DISCs charity Research Grant, London.

\section{Author details}

${ }^{1}$ Biomedical Research Centre, Sheffield Hallam University, Howard Street, Sheffield, South Yorkshire S1 1WB, UK. ${ }^{2}$ Sheffield Teaching Hospitals NHS Foundation Trust, Sheffield, UK.

Received: 14 May 2013 Accepted: 21 November 2013

Published: 11 December 2013

\section{References}

1. Liebscher T, Haefeli M, Wuertz K, Nerlich AG, Boos N: Age-related variation in cell density of human lumbar intervertebral disc. Spine 2011, 36:153-159.

2. Walmsley R: The development and growth of the intervertebral disc Edinb Med Journal 1953, 60:341-364.

3. Antoniou J, Steffen T, Nelson F, Winterbottom N, Hollander A, Poole R, Aebi M, Alini M: The human lumbar intervertebral disc - evidence for changes in the biosynthesis and denaturation of the extracellular matrix with growth, maturation, ageing, and degeneration. J Clin Invest 1996, 98:996-1003.

4. Adams M, Hutton W: Gradual disk prolapse. Spine 1985, 10:524-531.

5. Johnson W, Roberts S: Human intervertebral disc cell morphology and cytoskeletal composition: a preliminary study of regional variations in health and disease. J Anat 2003, 203:605-612.

6. Roberts S, Evans EH, Kletsas D, Jaffray DC, Eisenstein SM: Senescence in human intervertebral discs. Eur Spine J 2006, 15:S312-S316.

7. Gruber HE, Norton HJ, Ingram JA, Hanley EN: The SOX9 transcription factor in the human disc: Decreased immunolocalization with age and disc degeneration. Spine 2005, 30:625-630.

8. Rutges JPHJ, Duit RA, Kummer JA, Oner FC, van Rijen MH, Verbout AJ, Castelein RM, Dhert WJA, Creemers LB: Hypertrophic differentiation and calcification degeneration. Osteoarthritis Cartilage 2010, 18:1487-1495

9. Weiler C, Nerlich AG, Zipperer J, Bachmeier BE, Boos N: SSE award competition in basic science: expression of major matrix metalloproteinases is associated with intervertebral disc degradation and resorption. Eur Spine J 2002, 2002:308-320.

10. Park J, Chang H, Kim K: Expression of fas ligand and apoptosis of disc cells in herniated lumbar disc tissue. Spine 2001, 26:618-621.

11. Wang H, Liu H, Zheng Z, Zhang K, Wang T, Sribastav S, Liu W, Liu T: Role of death receptor, mitochondrial and endoplasmic reticulum pathways in different stages of degenerative human lumbar disc. Apoptosis 2011 16:990-1003.

12. Weiler $C$, Nerlich AG, Bachmeier BE, Boos N: Expression and distribution of tumor necrosis factor alpha in human lumbar intervertebral discs: a study in surgical specimen and autopsy controls. Spine 2005, 30:44-53.

13. Bachmeier BE, Nerlich AG, Weiler C, Paesold G, Jochum M, Boos N: Analysis of tissue distribution of TNF-alpha, TNF-alpha-receptors, and the activating TNF-alpha-converting enzyme suggests activation of the TNF-alpha system in the aging intervertebral disc. Ann NY Acad Sci 2007, 1096:44-54

14. Ahn SH, Cho YW, Ahn MW, Jang SH, Sohn YK, Kim HS: mRNA expression of cytokines and chemokines in herniated lumbar intervertebral discs. Spine 2002, 27:911-917.

15. Le Maitre CL, Freemont AJ, Hoyland JA: The role of interleukin-1 in the pathogenesis of human intervertebral disc degeneration. Arthritis Res Ther 2005, 7:R732-R745.

16. Le Maitre CL, Hoyland JA, Freemont AJ: Catabolic cytokine expression in degenerate and herniated human intervertebral discs: IL-1 beta and TNF alpha expression profile. Arthritis Res Ther 2007, 9:R77.

17. Hoyland JA, Le Maitre C, Freemont AJ: Investigation of the role of IL-1 and TNF in matrix degradation in the intervertebral disc. Rheumatology 2008, 47:809-814

18. Millward-Sadler SJ, Costello PW, Freemont AJ, Hoyland JA: Regulation of catabolic gene expression in normal and degenerate human intervertebral disc cells: implications for the pathogenesis of intervertebral disc degeneration. Arthritis Res Ther 2009, 11:R65 
19. Studer RK, Vo N, Sowa G, Ondeck C, Kang J: Human nucleus pulposus cells react to IL-6: Independent actions and amplification of response to IL-1 and TNF-alpha. Spine (Phila Pa 1976) 2011, 36:593-599.

20. Adams MA, Hutton WC: Prolapsed intervertebral disc; A hyperflexion injury. Spine 1982, 7:184-191

21. Adams M, Freeman B, Morrison H, Nelson I, Dolan P: Mechanical initiation of intervertebral disc degeneration. Spine 2000, 25:1625-1636.

22. Lama P, Le Maitre CL, Dolan P, Tarlton JF, Harding IJ, Adams MA: Do intervertebral discs degenerate before they herniate, or after? Bone Joint J 2013, 95-B:1127-1133.

23. Key JA: Intervertebral disc lesions are the most common cause of low back pain with or without sciatica. Ann Surg 1945, 121:534-539.

24. Teplick J, Haskin M: Spontaneous regression of herniated nucleus pulposus. Am J Neuroradiol 1985, 6:331-335.

25. Keskil S, Ayberk G, Evliyaoglu C, Kizartici T, Yucel E, Anbarci H: Spontaneous resolution of "protruded" lumbar discs. Minim Invasive Neurosurg 2004, 47:226-229.

26. Kawaguchi S, Yamashita T, Katahira G, Yokozawa H, Torigoe T, Sato N: Chemokine profile of herniated intervertebral discs infiltrated with monocytes and macrophages. Spine 2002, 27:1511-1516.

27. Kanerva A, Kommonen B, Gronblad M, Tolonen J, Habtemariam A, Virri J, Karaharju E: Inflammatory cells in experimental intervertebral disc injury. Spine 1997, 22:2711-2715.

28. Habtemariam A, Gronblad M, Virri J, Seitsalo S, Karaharju E: A comparative immunohistochemical study of inflammatory cells in acute-stage and chronic-stage disc herniations. Spine 1998, 23:2159-2165.

29. Kobayashi S, Meir A, Kokubo Y, Uchida K, Takeno K, Miyazaki T, Yayama T, Kubota M, Nomura E, Mwaka E, Baba H: Ultrastructural analysis on lumbar disc herniation using surgical specimens role of neovascularization and macrophages in hernias. Spine 2009, 34:655-662.

30. Bertram H, Kroeber M, Wang H, Unglaub F, Guehring T, Carstens C, Richter W: Matrix-assisted cell transfer for intervertebral disc cell therapy. Biochem Biophys Res Commun 2005, 331:1185-1192.

31. Steck E, Bertram H, Abel R, Chen B, Winter A, Richter W: Induction of intervertebral disc-like cells from adult mesenchymal stem cells. Stem Cells 2005, 23:403-411.

32. Le Maitre $C L$, Baird P, Freemont AJ, Hoyland $J A$ : An in vitro study investigating the survival and phenotype of mesenchymal stem cells following injection into nucleus pulposus tissue. Arthritis Res Ther 2009, 11:R20.

33. Nomura T, Mochida J, Okuma M, Nishimura K, Sakabe K: Nucleus pulposus allograft retards intervertebral disc degeneration. Clin Orthop 2001, 389:94-101

34. Sakai D, Mochida J, Yamamoto $Y$, Nomura T, Okuma M, Nishimura K Nakai T, Ando K, Hotta T: Transplantation of mesenchymal stem cells embedded in atelocollagen((R)) gel to the intervertebral disc: a potential therapeutic model for disc degeneration. Biomaterials 2003, 24:3531-3541.

35. Yang Z, Huang CC, Candiotti KA, Zeng X, Yuan T, Li J, Yu H, Abdi S: Sox-9 facilitates differentiation of adipose tissue-derived stem cells into a chondrocyte-like phenotype in vitro. J Orthop Res 2011, 29:1291-1297.

36. Lee S, Moon CS, Sul D, Lee J, Bae M, Hong Y, Lee M, Choi S, Derby R, Kim B, Kim J, Yoon J, Wolfer L, Kim J, Wang J, Hwang S, Lee S: Comparison of growth factor and cytokine expression in patients with degenerated disc disease and herniated nucleus pulposus. Clin Biochem 2009, 42:1504-1511.

37. Wang J, Tian Y, Phillips KLE, Chiverton N, Haddock G, Bunning RAD, Cross AK, Shapiro IM, LeMaitre CL, Risbud MV: TNF- $\alpha$ and IL-1 $\beta$ dependent induction of CCL3 expression by nucleus pulposus cells promotes macrophage migration through CCR1. Arthritis Rheum 2013, 65:832-842.

38. Shamji MF, Setton LA, Jarvis W, So S, Chen J, Jing L, Bullock R, Isaacs RE, Brown C, Richardson WJ: Proinflammatory cytokine expression profile in degenerated and herniated human intervertebral disc tissues. Arthritis Rheum 2010, 62:1974-1982.

39. Roberts S, Evans H, Trivedi J, Menage J: Histology and pathology of the human intervertebral disc. J Bone Joint Surg Am 2006, 88A:10-14.

40. Phillips KLE, Jordan-Mahy N, Nicklin MHN, LeMaitre CL: Interleukin-1 receptor antagonist deficient mice provide insights into pathogenesis of human intervertebral disc degeneration. Ann Rheum Dis 2013, 72:1860-1867.

41. Pockert AJ, Richardson SM, Le Maitre CL, Lyon M, Deakin JA, Buttle DJ, Freemont AJ, Hoyland JA: Modified expression of the ADAMTS enzymes and tissue inhibitor of metalloproteinases 3 during human intervertebral disc degeneration. Arthritis Rheum 2009, 60:482-491.

42. Kawaguchi S, Yamashita T, Yokogushi K, Murakami T, Ohwada O, Sato N: Immunophenotypic analysis of the inflammatory infiltrates in herniated intervertebral discs. Spine 2001, 26:1209-1214

43. Bobechko WP, Hirsch C: Auto-immune response to nucleus pulposus in the rabbit. J Bone Joint Surg Br 1965, 47:574-580.

44. Marshall $\mathrm{L}$, Trethewie $\mathrm{E}$, Curtain C: Chemical radiculitis - clinical, physiological and immunological study. Clin Orthop 1977, 129:61-67.

45. Satoh K, Konno S, Nishiyama K, Olmarker K, Kikuchi S: Presence and distribution of antigen-antibody complexes in the herniated nucleus pulposus. Spine 1999, 24:1980-1984.

46. Geiss A, Larsson K, Rydevik B, Takahashi I, Olmarker K: Autoimmune properties of nucleus pulposus - an experimental study in pigs. Spine 2007, 32:168-173.

47. Geiss A, Larsson K, Junevik K, Rydevik B, Olmarker K: Autologous nucleus pulposus primes $T$ cells to develop into interleukin-4-producing effector cells: an experimental study on the autoimmune properties of nucleus pulposus. J Orthop Res 2009, 27:97-103.

48. Hassler $\mathrm{O}$ : The human intervertebral disc. A micro-angiographical study on its vascular supply at various ages. Acta Orthop Scand 1969, 40:765-772.

49. Guinto F, Hashim H, Stumer M: CT demonstration of disk regression after conservative therapy. Am J Neuroradiol 1984, 5:632-633.

50. Mazzetti E, Magagnoli G, Paoletti S, Uguccioni M, Olivotto E, Vitellozzi R, Cattini L, Facchini A, Borzi R: A role for chemokines in the induction of chondrocyte phenotype modulation. Arthritis Rheum 2004, 50:112-122.

51. Merz D, Liu R, Johnson K, Terkeltaub R: IL-8/CXCL8 and growth-related oncogene alpha/CXCL1 induce chondrocyte hypertrophic differentiation. $\mathrm{J}$ Immunol 2003, 171:4406-4415.

52. Wei L, Kanbe K, Lee M, Wei X, Pei M, Sun X, Terek R, Chen Q: Stimulation of chondrocyte hypertrophy by chemokine stromal cell-derived factor 1 in the chondro-osseous junction during endochondral bone formation. Dev Biol 2010, 341:236-245

53. Alaaeddine $\mathrm{N}$, Olee T, Hashimoto S, Creighton-Achermann L, Lotz M: Production of the chemokine RANTES by articular chondrocytes and role in cartilage degradation. Arthritis Rheum 2001, 44:1633-1643.

54. Yuan GH, Masuko-Hongo K, Sakata M, Tsuruha Jl, Onuma H, Nakamura H, Aoki $\mathrm{H}$, Kato T, Nishioka K: The role of $\mathrm{C}-\mathrm{C}$ chemokines and their receptors in osteoarthritis. Arthritis Rheum 2001, 44:1056-1070.

55. Borzi R, Mazzetti I, Magagnoli G, Paoletti S, Uguccioni M, Gatti R, Orlandini G, Cattini L, Facchini A: Growth-related oncogene alpha induction of apoptosis in osteoarthritis chondrocytes. Arthritis Rheum 2002, 46:3201-3211.

56. Wei L, Sun X, Kanbe K, Wang Z, Sun C, Terek R, Chen Q: Chondrocyte death induced by pathological concentration of chemokine stromal cell-derived factor-1. J Rheumato/ 2006, 33:1818-1826.

\section{doi:10.1186/ar4408}

Cite this article as: Phillips et al:: The cytokine and chemokine expression profile of nucleus pulposus cells: implications for degeneration and regeneration of the intervertebral disc. Arthritis Research \& Therapy 2013 15:R213.

\section{Submit your next manuscript to BioMed Central and take full advantage of:}

- Convenient online submission

- Thorough peer review

- No space constraints or color figure charges

- Immediate publication on acceptance

- Inclusion in PubMed, CAS, Scopus and Google Scholar

- Research which is freely available for redistribution 